\title{
ナノ界面系の光や電圧に対する応答の理論研究
}

\section{Theoretical Study on Response of Nanointerface Systems to Light and Voltage Bias}

\author{
飯田 健二
}

Kenji Iida

\begin{abstract}
Heterogeneous systems consisting with nanomaterials (hereafter referred to as nanointerface systems) are extensively investigated in relation to interests in batteries, photo-and electro-catalysts, solar cells, and optoelectronic devices. To efficiently design these functional materials, it is required to obtain atomic-scale insights into the response mechanism to light and voltage bias. However, first-principles theoretical studies on nanointerface systems under light and voltage bias have been scarcely performed because of two problems. Firstly, a huge computational cost is needed to calculate a nanointerface system with a first-principles computational method. Secondly, it is difficult to theoretically describe electronic structure explicitly considering light and voltage bias. In this review, we report the recent progress in our theoretical and computational studies on nanointerface systems. The optical response of various systems such as a gold-thiolate nanocluster and a $\mathrm{MoS}_{2}$-graphene heterostructure has been simulated using a first-principles computational method for carrying out massively parallel calculations of photoexcited electron dynamics. The computational results have been analyzed with theoretical formulas for revealing the role of the interface region in the optical response. We have also developed an original theoretical method for investigating electrode systems. The developed method has been used to elucidate the mechanism of the electronic structure change inherent in nanointerface systems by applying bias voltage, which causes the electronic charging and generates the electric field from a gate electrode.
\end{abstract}

Keywords: Interface, Voltage, Light, Nanomaterial, First-principles calculation

\section{1.はじめに}

光や電圧に対する物質の応答は, 光触媒・電極材料・電 子デバイスなどの開発のために広く研究が行われてきた。 基礎学術的な観点からも興味深く，系を構成する物質の組 み合わせに応じて光エネルギー移動・光電変換・電気化学 反応といった様々な現象が発現する。これらの現象を理解 するために，物質相界面の役割を明らかにすることは重要 な課題として位置づけられてきた。そうした中で，数 $\mathrm{nm}$ サイズの物質を用いて構成されたへテロな構造を有する系 （以下，ナノ界面系と呼ぶ）が開発されるようになってきた。 例えば，様々な幾何的構造を有する金チオラートクラス ターが合成されて，X 線結晶構造が報告されている ${ }^{1-3}$ 。ま た，グラフェンや遷移金属ダイカルコゲナイドといった二 次元層状物質を積層した系が作成されている ${ }^{4}$ 。物質開発 とともに，物質表面に分子や金属ナノ粒子を担持する技術 も進歩している。新たな物質や技術を組み合わせて創製さ れるナノ界面系の光・電子物性を制御するためには，界面 の役割に対する原子レベルの知見が求められる。

分子やクラスターといった 100 原子程度以下の物質の幾 何構造や電子物性は, 量子化学計算を用いて広く研究が行 われてきた。それより遥かに大きなバルクの物質は，周期 的な構造を持つ均一系と捉えられ，バンド計算によって理
解が深められてきた。しかし両者の中間の大きさの系とな ると，周期境界条件を課すことが出来ないために，大規模 な計算が必要となる。また，基底状態計算の手法に比べる と，光や電圧に対する電子の応答を扱うための理論的手法 の開発はあまり進んでこなかった。これら理論開発の遅れ と計算コストという質的・量的な問題があるために，ナノ 界面系の理論計算研究は殆どなされていなかった。そのよ うな中で，著者らは，光励起電子ダイナミクスの超並列第 一原理計算を行うためのプログラムの開発に携わるととも に，ナノ界面系の光励起を解析するための手法を整備して きた。また，電圧を印加した系の電子状態を計算するため の理論的手法の開発を行ってきた。そして，開発した手法 を用いて，ナノ界面系の光や電圧に対する応答の大規模計 算を行い，小分子やバルクの物質とは異なるナノ界面系に 特有の外場応答機構を明らかにしてきた。本総説では，ナ ノ界面系の光や電圧に対する応答機構について，2 節で一 般的な内容を説明した後に，3 節以降で著者らの研究を中 心に紹介する。

\section{2. ナノ界面系の電子・幾何構造}

ナノ界面系の電子 ・幾何構造の特性は, 外場応答におい て重要な役割を果たす。まず，界面は考えず大きさに焦点 
を当てて，金属を例に取り考える。数個の原子からなる小 さなクラスターは離散的なエネルギー準位を有しており， 電子は各軌道に束縛される。原子数が増えていくにつれて, 準位間のエネルギー差は小さくなる。そしてバルクの半無 限系では, 電子は物質内を自由に移動する。直径数〜数十 $\mathrm{nm}$ の金属ナノ粒子は, 小さなクラスターとバルクの系の両 者に共通する特徴を持つ。準位間のエネルギー差が非常に 小さいため, バルク系と同様に, 電子は物質内をほぼ自由 に動く。一方で, 光との相互作用を考える場合には, 系の サイズは光の波長 (可視光なら数百 $\mathrm{nm}$ ) に比べて十分小さ いために，小さなクラスターと同じく有限系とみなされる。 従って, 有限空間内での自由電子の集団的な振動運動が特 定の波長の光によって共鳴励起される。この励起は, Localized Surface Plasmon Resonance (LSPR) と呼ばれ, 光科学 の分野で盛んに研究されている ${ }^{5-7}$ 。つまり, 数〜数十 $\mathrm{nm}$ のナノ粒子は, 小さなクラスターとバルクの物質の両者の 特徴を有するがゆえに, 特有の光学応答が発現する。

金属については, サイズが $10 \mathrm{~nm}$ 程度になると電子構造 はバルクの系のものに変化する。一方で, バルクの系とも 小分子とも異なる電子構造の表現がなされるナノ物質が存 在する。孤立分子の電子構造（Figure 1 (a)）は, 離散的な エネルギー差を有する分子軌道で特徴づけられる。外部電 圧や光といった外場で電子数が増減 (酸化還元) すると物 性が大きく変化する。一方，バルクの金属（Figure 1 (c)） では，フェルミレベルが電子物性を決めるうえで重要とな る。状態数は無限とみなされて, 電子が流出入しても, 状 態数に比べて電子占有数の変化量は非常に小さい。従って, 外場によって電子が流出入しても化学的に安定なままで物 性はあまり変化しない。グラフェン（Figure 1（b)）は, 分 子ともバルクの系とも異なる電子構造の表現がなされるナ ノ物質の代表例である。デイラックコーンで電子構造が特 徵づけられて, 原子レベルの厚みしかないのでフェルミレ ベル近傍の状態密度が非常に小さい。従って, 電子が流出 入すると, 状態数に対する電子占有数の変化が大きいため に, 伝導度や光吸収特性が有意に変化する ${ }^{8,9}$ 。しかし, バ ルク系と同じく連続な状態を有する半無限系でもあるので, 外場を印加しても化学的安定性は維持される。そのため, 異種物質を担持・積層することで, 外場による電子物性変 化が電極材料 ・ トランジスター・受光素子へと応用されて いる4。
次に，界面に着目して考える。バルクの物質だけを組み 合わせた系では，界面領域よりも内部の比率が遥かに大き い。従って，系を構成する物質の電子物性をベースとした バンドダイアグラムで外場応答機構の解釈がなされてき た ${ }^{10}$ 。しかし，界面の不純物や欠陥で生じる準位が外場応 答を支配しうることが度々指摘されて，界面に対する原子 レベルの知見が求められていた。更にナノ界面系になると, 界面領域は大きな比率を有しているために光・電子物性を 決定づける中心的な役割を担う。近年では, 外場を用いて 界面での相互作用を誘起することで光・電子物性の改変が なされている。例えば, 2 層グラフェンについて, 電極電 場を印加すると半金属から半導体へと変化することが報告 されて強く注目を集めた ${ }^{11}$ 。また, ナノ粒子を組み込んだ 系では, 光電場による分極で界面において強い電子的相互 作用が誘起される。簡単のため, 半径 $a$ で誘電率 $\varepsilon$ の球体 を考える。 $a$ は光の波長に比べて十分小さいとすると, 光 電場 $\left(E_{0}\right)$ による分極で生じる電場は, 以下の双極子 $\mu$ が 作るものとして与えられる ${ }^{6,12}$ 。

$$
\mu=\frac{\varepsilon-1}{2 \varepsilon+1} a^{3} E_{0}
$$

双極子の作る電場は距離の -3 乗に比例して減衰するので, 粒子の表面近傍のみで強い電場が生じる。また, 粒子サイ ズが大きくなるほど， $\mu$ が大きくなるため，周囲に発する 電場は増大する。従って, ナノ粒子が光励起すると, 周囲 の物質と接触した界面で強い相互作用が誘起される。それ により，光物性変化やエネルギー移動が生じる。

\section{3. 光学応答 \\ 3.1 理論計算手法}

物理化学現象を原子・電子のレベルで解析するために, 理論計算手法は広く使われてきた。分子や小さなクラス ターには量子化学計算が用いられている。ガウス型の基底 関数を用いて体積積分を解析的に行うことで, 計算が効率 化されている。一方，バルクの物質は平面波基底を用いた バンド計算で研究が行われている。高い併進対称性を持つ 物質は，周期境界条件を課すことで小さなユニットセルで 扱うことができる。しかし，量子化学計算やバンド計算の プログラムに含まれるフーリエ変換や対角化のプログラム は並列化が容易ではなく，系のサイズが大きくなるにつれ て急激に計算コストが増大する。また，基底状態を扱える

\section{(a) Molecule}

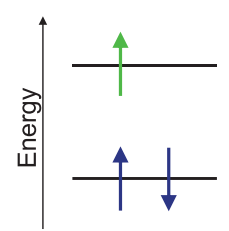

(b) Ex : Graphene

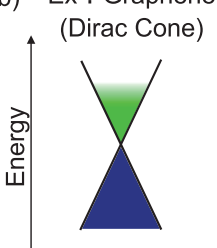

(c) Bulk Metal

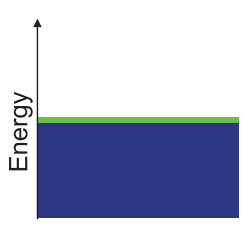

Figure 1. Scheme of charging of (a) an isolated molecule, (b) a nanointerface system, (c) a bulk metal. 
プログラムに比べると，外場に対する電子の動的応答に適 用できるものは限られていた。従って, ナノ界面系の理論 研究は, 系の一部を切り出して電子・幾何構造を解析する か, もしくは単純化したモデルを用いて現象論的な解釈を 行うに留まっていた。

数ナノメートルサイズの物質に対する原子・電子レベル の知見を得るべく, 超並列計算が可能なプログラムの開発 が行われてきた。数々のプログラムが開発されているが, 外場応答の超並列計算を行うためのプログラムとしては SALMON (Scalable Ab-initio Light-Mater simulator for Optics and Nanoparticles）が挙げられる ${ }^{13}$ 。SALMON では, 時間 依存の Kohn-Sham 方程式

$$
i \frac{\partial}{\partial t} \varphi_{i}(\mathbf{r}, t)=\left[H_{\mathrm{iso}}+V_{\mathrm{ext}}\right] \varphi_{i}(\mathbf{r}, t)
$$

を三次元実空間上のグリッド点を基底として差分法を用い て直接解く。つまり，空間をグリッド状に離散化して，グ リッド点上での值で軌道 $\varphi_{i}$ を表現する。ここで, $H_{\mathrm{iso}}$ は孤 立系に対するハミルトニアン， $V_{\mathrm{ext}}$ はレーザー電場である。 ガウス基底や平面波基底を用いる手法に比べてアルゴリズ ムがシンプルなために, 並列化が比較的容易である。具体 的には, MPI と OpenMPのハイブリッド並列を採用してい る。（2）式の時間発展を, 軌道・空間グリッド点・ $\mathrm{k}$ 点に 関して分割してMPI 並列で計算する。そして各プロセスで はOpenMP 並列が行われる。系に応じて並列数の配分を調 整することで, 各プロセスの計算量を均等にしつつ通信負 荷が抑えられる。数万 $\mathrm{cpu}$ まで高い並列化効率を維持する ため, 大規模計算によってナノ界面系を含めた様々な系に 適用できる。また，光と物質の相互作用が $V_{\mathrm{ext}}$ によって露 わに取り达まれているため, 様々な光学応答を記述するこ とができる。我々は, SALMONを用いてナノ界面系の光学 応答の研究を行ってきた。

\section{2 金属ナノクラスター}

貴金属からなるナノクラスターの LSPR は可視光で励起 され，その着色剂への利用は古代ローマにまで遡る ${ }^{14}$ 。現 在では, 強い光励起を利用した太陽電池の開発, 発する熱 を利用したがん治療, 入射光電場よりも数桁強くなる光誘 起電場を用いた化学センサーへと応用研究が広がっている。 基礎研究も盛んに続けられている。直径十数 $\mathrm{nm}$ 以上の貴 金属ナノ粒子の LSPR 特性は, 物質を一様な媒体と近似し て古典電磁気学計算手法を適用することで研究がなされて きた。しかし近年, 銀ナノ粒子のサイズが $10 \mathrm{~nm}$ よりも小 さくなると, 急激にLSPRの共鳴エネルギーが増加して, 一 様な媒体と近似した結果から大きく外れることが明らかに なった ${ }^{15}$ 。また, 金ナノ粒子二量体間の距離を $3 \AA$ 以下に 近づけると, 粒子間の電子移動が光学特性に大きく影響を 及ぼすことが報告された ${ }^{16}$ 。従って, 量子力学に立脚した 原子・電子レベルの理解が求められている。
著者らは，スーパーコンピューター「京」を用いて，金 ナノクラスターの光励起の超並列計算を行った ${ }^{17}$ 。計算に は, SALMONの元となったプログラムである GCEED を用 いた。クラスターの形状は正 20 面体に固定して, サイズ依 存性を解析した。光吸収スペクトルを Figure 2（a）に示す。 308 原子のクラスターでは $2.6 \mathrm{eV}$ 付近にみられるピークが 1414 原子のクラスター（直径約 $4 \mathrm{~nm}$ ）では $2.3 \mathrm{eV}$ ヘレッ ドシフトしている。同様の振る舞いは，金や銀のナノ粒子 の実験で報告されている ${ }^{15,18}$ 。Figure 2 (b) に，吸収ピー ク位置の光エネルギーに対する誘起電子密度分布を示す。 赤と青の分布がプラスとマイナスに対応しており, 光電場 によって両者の間を往復する。小さなクラスターでは, 離 散的な準位間で遷移するために, 赤と青の分布が複雑に入

(a)

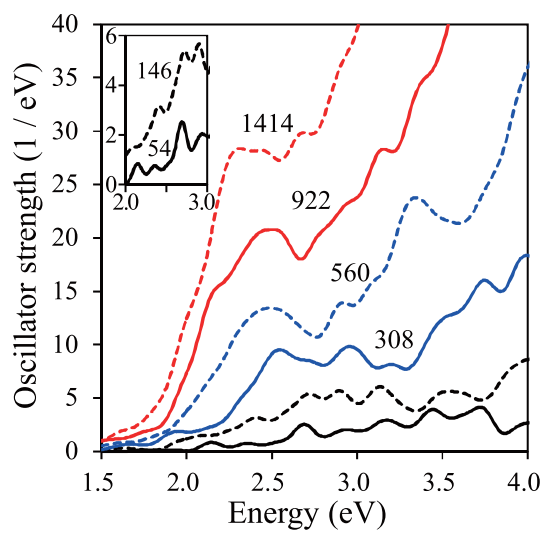

(b)
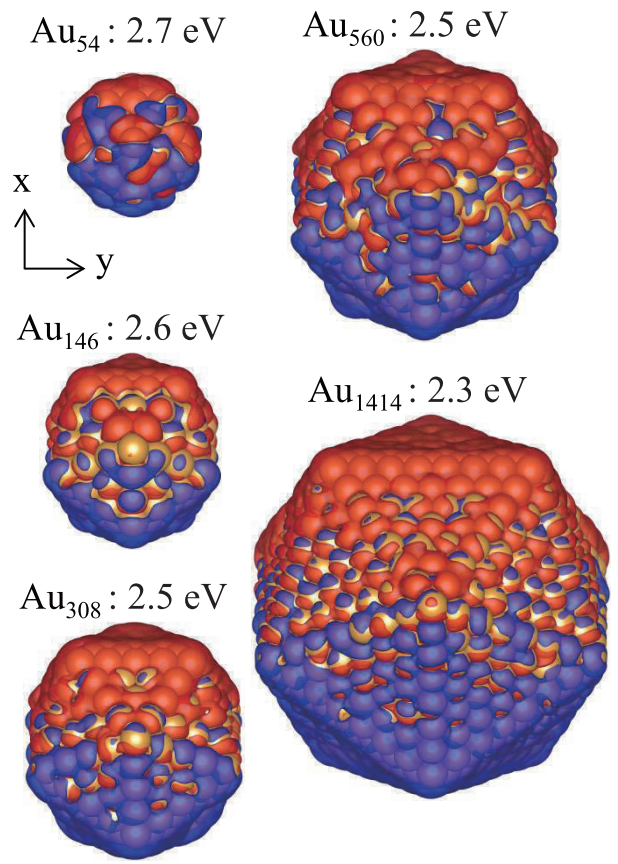

Figure 2. (a) Oscillator strengths of $\mathrm{Au}_{n}(n=54,146,308,560,922$, and 1414) and (b) photo-induced electron densities of $\mathrm{Au}_{n}(n=54,146$, 308,560 , and 1414) seen from the direction perpendicular to the $x-y$ plane. The applied laser energies are indicated in the unit of eV. Adapted with permission from Ref. (17). Copyright 2014 American Chemical Society. 
り乱れている。サイズが大きくなるにつれて，分布が明瞭 に分離している。これは, 光電場に対して自由電子的に応 答して集団運動するためである。LSPR の成長過程を第一 原理に立脚して明らかにすることに成功した。

\section{3 金チオラートナノクラスター}

金チオラートクラスターは金のコアとそれを取り囲むリ ガンドからなる物質である。 $\mathrm{Au}_{25}$ をコアとするクラスター を始めとして, リガンドとコアの化学組成や幾何的形状を 変えて様々なクラスターが合成されてきた ${ }^{1,2}$ 。そして 2015 年に, それまでのクラスターに比べて遥かに大きな $\mathrm{Au}_{133}$ をコアとするクラスター $\mathrm{Au}_{133}\left(\mathrm{SPh}-\mathrm{tBu}_{3}\right)_{52}$ の x 線結晶構造 が報告された ${ }^{19,20}$ 。比較的かさ高いコアとリガンドの間に は界面が存在するが，その光学応答における役割は明らか にされていなかった。そこで著者らは, $\mathrm{Au}_{133}\left(\mathrm{SPh}-\mathrm{tBu}_{3}\right)_{52}$ の光励起における界面の役割を明らかにするべく研究を 行った ${ }^{21}$ 。

Figure 3 (a) は計算から得られた光吸収スペクトルである。 $1.5 \mathrm{eV}$ 付近の小さなピークと $2-3 \mathrm{eV}$ にあるふたこぶ型の分 布が特徵的であり，これらは実験結果と定性的に一致する。 比較のために, $\mathrm{Au}_{146}$ の結果も示している。 $\mathrm{Au}_{133}\left(\mathrm{SPh}-\mathrm{HBu}_{3}\right)_{52}$

(a)

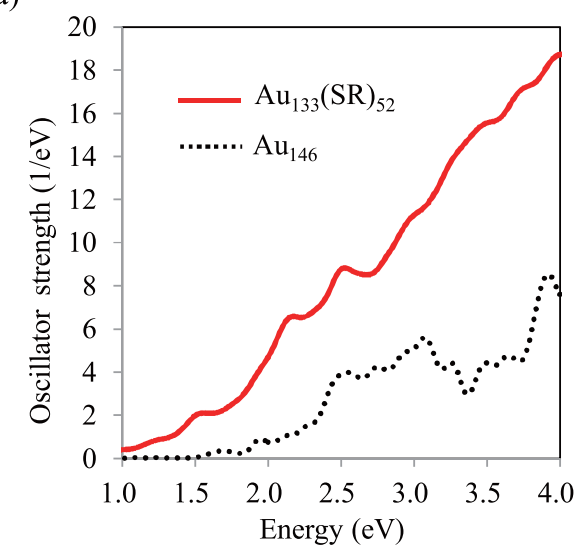

(b)

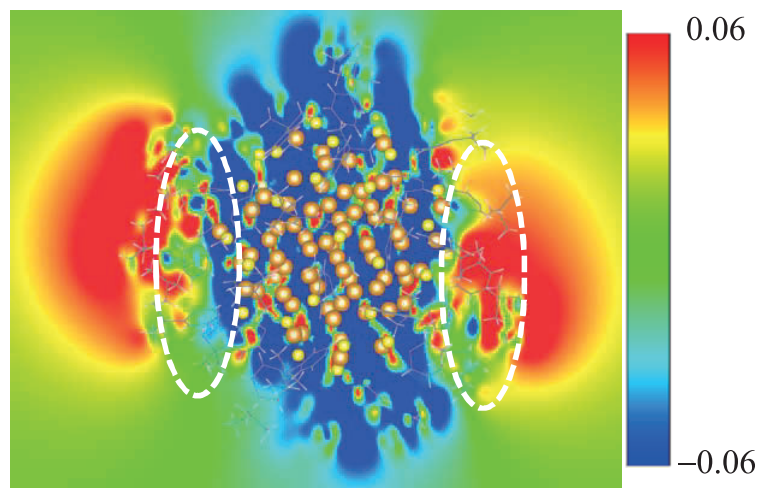

Figure 3. (a) Optical absorption spectra of $\mathrm{Au}_{133}\left(\mathrm{SPh}-\mathrm{tBu}_{3}\right)_{52}$ (solid red line) and $\mathrm{Au}_{146}$ (dotted black line). (b) Contour map of the imaginary part of photoinduced electric field in $\mathrm{Au}_{133}(\mathrm{SR})_{52}$. Adapted with permission from Ref. (21). Copyright 2016 American Chemical Society.
の光吸収強度は, $\mathrm{Au}_{146}$ に比べてはるかに大きい。しかし， リガンドだけを取り出した計算では, 可視光帯に吸収は得 られなかった。つまり, 金とリガンドの間の界面が吸収強 度の増大を引き起こしている。

界面の役割を明らかにするべく，光励起の機構を解析し た。ナノ界面系では多数の準位間で遷移が生じるために, 少数の分子軌道に着目する従来の解析は意味をなさない。 まず, 光誘起電子密度分布を調べたが, 分布は非常に複雑 であり，物理化学的に意味のある特徵は見出されなかった。 そこで，光による電子分極で誘起される電場に着目した。 金チオラートクラスターの光誘起電場を Figure 3 (b) に示 す。赤と青の分布は, それぞれ光電場に対して同方向と逆 方向の電場である。尚, 光自体の電場は含めていない。金 コアの内部では青い分布があり, クラスターの外には赤い 分布がある。この分布は, 双極子放射場が形成されたこと を示している。更に, 白点線で囲ったリガンド部分には電 場が生じていない緑の領域が存在する。この緑の領域は, 金コア表面での電子分極で生じる電場がリガンドの電子分 極によって打ち消されることで生じる。これは，金コア／ チオラート界面は電子を通さない絶縁的な振る舞いをして いるということを示す。

界面は，構成物質の組み合わせに応じて様々な電子物性 を有している。例えば, 異種の金属酸化物を接合することで 導電性のある界面が形成されることが知られている ${ }^{22}$ 。本 研究では, 第一原理に立脚した計算から, $\mathrm{Au}_{133}(\mathrm{SPh}-\mathrm{tBu})_{52}$ の界面は光励起において絶縁的な振る舞いをすることが見 出された。そこで, コアシェル型の誘電体モデルを用いて, シェルによる光吸収強度の変化を見積もった。コアシェル 型物質の分極率は以下で与えられる。

$$
\alpha_{\mathrm{c}-\mathrm{s}}=\frac{\left(a_{1}+a_{2}\right)^{3}\left(\varepsilon_{2}-1\right)\left(\varepsilon_{1}+2 \varepsilon_{2}\right)+a_{1}^{3}\left(2 \varepsilon_{2}+1\right)\left(\varepsilon_{1}-\varepsilon_{2}\right)}{\left(a_{1}+a_{2}\right)^{3}\left(\varepsilon_{2}+2\right)\left(\varepsilon_{1}+2 \varepsilon_{2}\right)+a_{1}^{3}\left(2 \varepsilon_{2}-2\right)\left(\varepsilon_{1}-\varepsilon_{2}\right)}
$$

ここで, $a_{1}, a_{2}$ と $\varepsilon_{1}, \varepsilon_{2}$ は金属コアとリガンド層の半径と誘 電率である。金属コアとリガンド層に個別の物理パラメー ターが与えられるのは，電子系としては界面を境に分離さ れて光応答するためである。（3）式を用いて分極率の虚部 を見積もったところ, リガンド層によって光吸収強度は 2.5 倍強くなるという第一原理計算と定性的に一致する結果が 得られた。以上の解析から，金コア/リガンド界面におけ る電子的な相互作用によって, 光吸収強度が増大すること が明らかになった。また，この光吸収の増大はリガンド層 と金コアが比較的かさ高いことに由来する。これは，実際 の大規模な系を計算することが，界面の役割を解明するの に必要であったことを示す。

\section{4 貴金属一半導体界面}

貴金属ナノクラスターを半導体薄膜に担持した系につい て, 光学応答の機構は主に二つの観点から議論されてきた。 
第一は，貴金属ナノクラスター／半導体界面での電子的相 互作用によるナノクラスターから半導体への共鳴エネル ギー移動である 23,24 。これは, LSPR で生じる強い光誘起電 場を利用しており, 太陽電池の効率化への応用が試みられ ている。第二は, LSPR で生じた励起電子のナノクラスター から半導体への移動である ${ }^{25,26}$ 。光触媒に応用されており， 反応に要する光の低エネルギー化が試みられている。しか し, 応用研究の進展に比して基礎的研究は進んでいなかっ た。例えば, 界面での電子的な相互作用の電子移動におけ る役割は明らかにされていなかった。また, 電子移動とエ ネルギー移動は個別に議論されてきたが, 銀ナノクラス ター／酸化チタンヘテロ構造では電子移動とエネルギー移 動の両者が指摘されている 27,28 。従って, 励起電子のダイ ナミクスの機構を明らかにすることが求められていた。

著者らは, 銀ナノクラスター／酸化チタンヘテロ構造の 光励起電子ダイナミクスを SALMON で計算した ${ }^{29}$ 。Figure 4 (a) は光照射による電子占有数の変化である。横軸は酸 化チタン層に垂直な方向であり, 酸化チタンと担持銀ナノ クラスターはそれぞれ左と右にある。縦軸はフェルミレベ ルを基準に取ったバンドエネルギーである。赤と青で電子 が増加及び減少した領域を示している。白の矢印は入射光 のエネルギー $(3 \mathrm{eV})$ 幅である。銀ナノクラスター側では, 価電子帯の電子が減少しているが, 伝導帯 (白点線) に励 起電子が全く存在しない。一方で, 酸化チタン側では, 伝 導帯に励起電子が蓄積している。さらに時間変化を調べた が, 経過時間によらず銀ナノクラスターの伝導帯に励起電 子は見出されなかった。この結果は, LSPR で生じた励起 電子は, 銀の伝導帯を経ることなく酸化チタンへと直接移 動することを示す (Figure 4（b）の経路 III）。比較のため に, $\mathrm{Ag}_{20}$ と $\mathrm{TiO}_{2}$ を個別に最適化して接合した系や $\mathrm{Ag}_{84}$ を 用いた系の計算も行ったが, 電子移動の機構に顕著な違い は見出されなかった。そこで，光によって誘起される電場 を解析したところ, 銀ナノクラスター／酸化チタン界面で の電子的相互作用によって電子が直接移動することが明ら かになった。

様々な金属ナノクラスター／半導体へテロ構造を対象と して光誘起電子移動の研究がなされてきた。これまでは, 金属ナノクラスターに励起電子が生じた後に半導体に電子 が移動するという, Figure 4（b）のII と IV からなる 2 段 階の経路が考えられてきた ${ }^{25,26}$ 。しかし, 光と物質の相互 作用を露わに考慮した電子ダイナミクス計算によって，電 子が銀から酸化チタンへ直接移動するという機構が見出さ れた。これまでの研究から, 金属ナノクラスター内に蓄積 した励起電子が速やかに失活するために, 光エネルギーの 利用効率が低いという問題が知られていた。本研究で明ら かになった電子移動の機構は, 光エネルギー利用の高効率 化に繋がると期待され, 更なる詳細な研究が求められる。 例えば, 界面準位が電子移動機構を支配するという指摘が
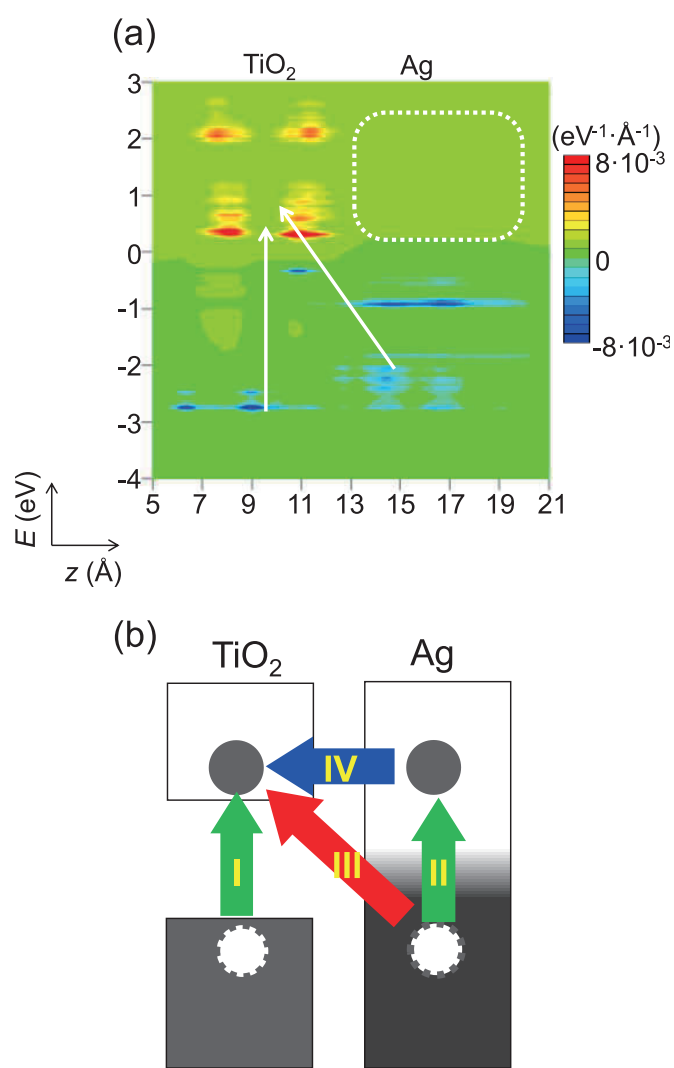

Figure 4. (a) Variations in the electron occupation number caused by photoexcitation of a silver nanocluster/ $/ \mathrm{TiO}_{2}$ heterostructure and (b) possible paths of electronic transition in a silver nanocluster/ $/ \mathrm{TiO}_{2}$ heterostructure (29).

なされている ${ }^{30}$ 。原子・電子のレベルの知見を与える分子 科学的アプローチによる理解の深化が求められる。

\section{5 二次元層状物質}

原子レベルの厚みを有する層状物質として，グラフェ ン・シリセン・フォスフォレン・遷移金属ダイカルコゲナ イドといった様々な系が合成されている 4 。2 節で述べたよ うに，原子レベルの厚みを有する層状物質では状態密度が 小さいことから, 外場によって電気伝導度や光吸収強度が 大きく変化する。グラフェンと $\mathrm{MoS}_{2}$ からなるへテロ構造 は広く研究されており, $\mathrm{MoS}_{2}$ とグラフェンの間の光誘起 電子移動を利用した光デバイスや光触媒の開発が進められ てきた ${ }^{31,32}$ 。そうした中で, 久陥や不純物の無い系を作成 することで，グラフェンから $\mathrm{MoS}_{2}$ への電子移動が凡そ 10 倍程度大きく発現するという報告がなされ ${ }^{33}$, 接触界面に 対する原子レベルの知見が求められている。しかし，異種 の原子層状物質からなる系の計算は容易ではない。グラ フェンのバンドエネルギーは K 点近傍で急峻に変化するた め, 光励起の計算には多数の $\mathrm{k}$ 点が必要となる。更に, 単 位格子サイズが異なる物質を接合した系を計算する場合, 小さなユニットセルでは格子歪みが大きくなる。従って， 非常に大きな系を扱うことが求められる。

著者らは，超並列第一原理計算によってグラフェン $-\mathrm{MoS}_{2}$ 


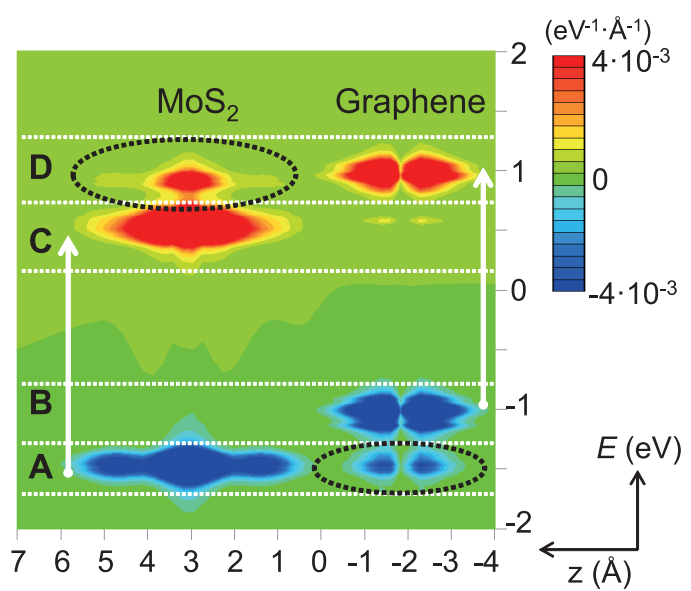

Figure 5. Variations in the electron occupation number due to the photoexcitation of the $\mathrm{MoS}_{2}$-graphene heterostructure. Adapted with permission from Ref. (34). Copyright 2018 American Chemical Society.

系の光誘起電子移動の研究を行った ${ }^{34}$ 。Figure 5 に光励起 に伴う電子占有数の変化を示す。横軸は原子層に垂直な方 向であり, $\mathrm{MoS}_{2}$ とグラフェンはそれぞれ左と右にある。縦 軸はフェルミレベルを基準に取ったバンドエネルギーであ る。黒点線で囲った所が, グラフェンと $\mathrm{MoS}_{2}$ が単独では 現れない分布である。この分布は，グラフェンから $\mathrm{MoS}_{2}$ へ電子が移動したことを示して扔り, 実験 ${ }^{33}$ と同様の結果 が得られた。そこで電子移動の機構を解析したところ， $\mathrm{MoS}_{2}$ とグラフェンの状態密度の大きさの違いが電子移動 の方向を決定づけていることを明らかにした。

\section{4. 電圧依存性}

\section{1 ナノ界面系への電圧印可}

電圧を印可した系は電池・電極触媒・電子デバイス・分 子センサーなどへの興味から広く研究がされてきた ${ }^{10,35}$ 。 近年では，グラフェンなどを用いて数原子程度の層からな る電極系を精密に作成することが可能になっており, バル クの金属と異なる電圧依存性が報告されている ${ }^{4,36}$ 。そして, 電極表面へ異種物質を担持することで, 電圧依存性の改変 が試みられている ${ }^{37}$ 。従って, 電圧依存性に対する電子。 原子レベルの理解の深化が求められている。

印加電圧の役割は, 電位の変化による電子の流出入と電 極電場による電子構造の変化という二つの観点から議論さ れてきた。グラフェンへの電圧印加による電子の流出入を 利用した系として, 縦型電界効果トランジスターと呼ばれ る,グラフェンと電極の間に半導体を挟んだ系があげられ る ${ }^{38}$ 。グラフェンで電子の流出入が生じると, フェルミレ ベル近傍の状態密度が小さいために, ディラック点とフェ ルミレベルの間のエネルギー差が変化する。すると, グラ フェンに接触した物質との間の電子移動障壁の高さが変化 してオンオフが切り替えられる。グラフェンの高い電気伝 導度を利用できる電子デバイスとして強く注目を集め, 様々な系に対して研究が行われてきた。電極電場による電
子構造の変化も盛んに研究されてきた。分子のシュタルク 効果の電極電場を用いた研究は古くからなされてきた。近 年では， 2 層積層したグラフェンに電極電場を印加すると 半金属から半導体へと変化することが報告されて強く注目 を集めた ${ }^{11}$ 。以下では, 電子の流出入と電極電場による電 子構造変化について，著者らの研究を中心に説明する。

\section{2 電子の流出入}

電極表面での電子の流出入が酸化還元反応や光物性変化 を引き起こすことは良く知られている。近年では，SERSや STM といった実験手法によって分子レベルの知見が得られ ている ${ }^{35,39}$ 。しかし，対応する理論計算研究は極めて少な い。これは, 汎用の理論計算手法が電子数一定を前提とし ているためである。電極系では電位が一定であり外界と電 子の流出入が生じるので，異なる手法が必要となる。電極 系を扱うための様々な理論的手法が開発されており 40-44, 代表例として有限温度密度沉関数法（FT-DFT）が挙げられ る ${ }^{45}$ 。FT-DFT 法では， 外界との間の電子の流出入をグラン ドカノニカルアンサンブルで記述し，ある電位に打ける電 子数をフェルミーディラック分布関数

$$
f(E)=\frac{1}{1+\exp \left(\frac{E-\mu}{k_{\mathrm{B}} T}\right)}
$$

から算出する。ここで $E$ は電子準位のエネルギー,$T$ は温 度，そして $\mu$ が電位に対応する化学ポテンシャルである。 FT-DFT に基づく手法は様々なグループで開発されており， その手法を適用することで電極系の理解が徐々に深められ てきた $46-50$ 。

著者らは，溶媒効果を誘電体モデルで取り込んだうえで 量子開放系に対して FT-DFT 計算を行う手法を開発した ${ }^{51}$ 。 理論の詳細は論文を参照にされたい。開発した手法を用い て, $\mathrm{Ag}^{+}$の $\mathrm{Ag}(111)$ 表面と $\mathrm{Au}(111)$ 表面への吸着エネルギー の電圧依存性を比較した。その結果，電圧によらず $\mathrm{Ag}(111)$ より $\mathrm{Au}(111)$ に吸着した方がエネルギーは低く安定化する ことが明らかになった。これは, $\mathrm{Au}(111)$ に吸着しやすい という電気化学測定の実験結果と一致する ${ }^{52}$ 。比較のため

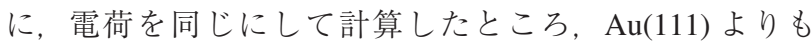
$\mathrm{Ag}(111)$ に吸着した方が安定化するという逆の結果が得ら れた。そこで，带電量の電圧依存性を計算したところ，同 じ電圧では $\mathrm{Ag}(111)$ よりも $\mathrm{Au}(111)$ の方が負に带電してい た。これより, 電気化学系に执いて $\mathrm{Ag}(111) よ り も \mathrm{Au}(111)$ に $\mathrm{Ag}^{+}$が吸着しやすい原因は, $\mathrm{Ag}^{+}$と静電的に強く相互作 用するためであると明らかになった。

\section{3 電極電場}

電極電場によるエネルギー準位の変化は，界面領域を久 ラブとして切り出して, 周期境界条件に合わせたノコギリ 


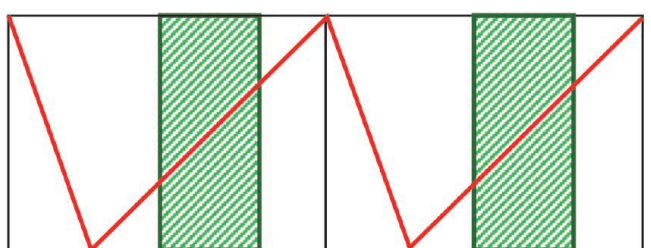

Figure 6. Saw-tooth-type electrostatic potential (red line) for simulating an external electric field. A slab is colored by green.

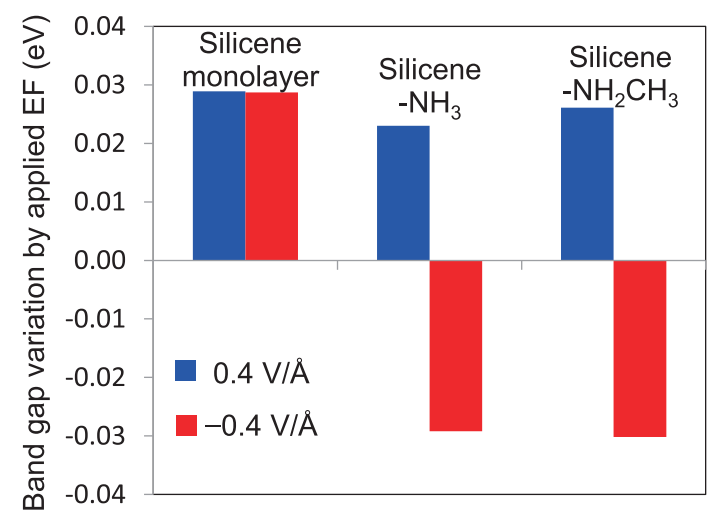

Figure 7. Applied electric-field dependence of the band-gap energies of a silicene monolayer, silicene- $\mathrm{NH}_{3}$, and silicene- $\mathrm{NH}_{2} \mathrm{CH}_{3}$ with respect to the gaps without applied electric fields. Reproduced from Ref. (57) with permission from the Royal Society of Chemistry.

型の静電ポテンシャルをハミルトニアンに加えるという手 法で計算が行われてきた (Figure 6) ${ }^{53-56}$ 。汎用のバンド計 算プログラムに実装された手法であり, 様々な系に適用さ れている。著者らは, Si からなる単原子層であるシリセン にアミン $\left(\mathrm{NH}_{2} \mathrm{CH}_{3}, \mathrm{NH}_{3}\right)$ が吸着した系を対象として, 電 場による電子構造変化を計算した ${ }^{57}$ 。シリセンはグラフェ ンに近い電子物性を有するが, 化学的にやや不安定性なた めに応用利用は進んでこなかった。しかし 2016 年に電極電 場を用いるデバイスが作成されて，シリセンに対する電極 電場の効果に注目が高まっている58。Figure 7 に印加電場 によるバンドギャップの変化を示す。シリセン単独では ギャップの変化は電場の符号に依存しない。しかしアミン が吸着すると, 正の電場で広くなり, 負の電場では逆に狭 くなる。そこで電子密度分布を調べたところ, アミンの吸 着に伴いアミンからシリセンに電子が移動していた。この 電子移動は, 正の電場で促進される一方で負の電場で弱め られる。化学結合と外部電場の組み合わせでバンドギャッ プの電界効果による変化が決定づけられていることを明ら かにした。

\section{4 電子の流出入と電極電場の統一的な取り扱い}

上述してきたように，電子物性の電圧依存性において， 電子の流出入と電極電場は重要な役割を果たす。しかし, 両者を取り扱うための理論的枠組みは全く異なるために, いずれかのみを考慮するに留まっていた。電圧依存性に対 する理解を深めるには, 両者を取り込んだ包括的な枠組み

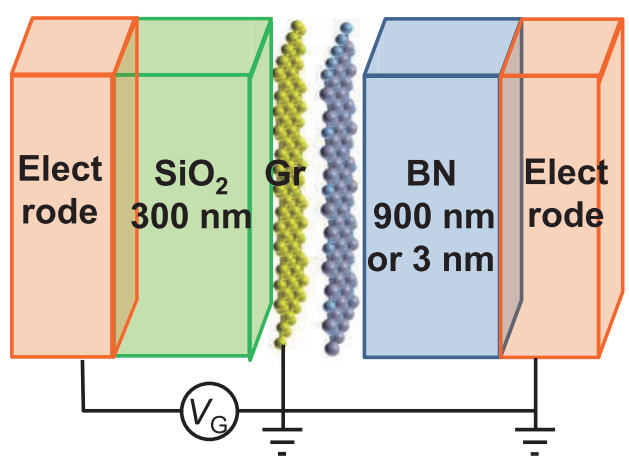

Figure 8. Schematic of the employed electrode system.

(a)

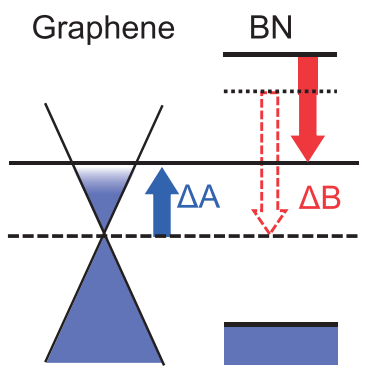

(b)

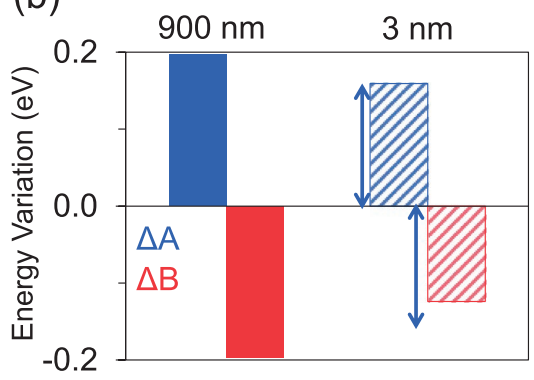

Figure 9. (a) Scheme of change in the band structure and (b) bandenergy variations with an applied bias of $60 \mathrm{~V}$ : $\Delta \mathrm{A}$ (blue) and $\Delta \mathrm{B}$ (red) with the 900-nm BN layer (solid) and with the 3-nm BN layer (hatched).

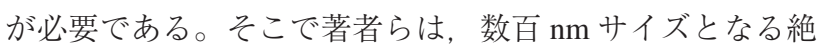
縁膜と対電極はマクロな媒体と近似することで, 実験条件 に則して電子の流出入と電極電場の両者を取り込むことが できる手法を開発した ${ }^{59}$ 。理論の詳細は論文を参照にされ たい。開発した手法を用いて, シリカ・グラフェン・窒化 ボロンを積層した電極系（Figure 8）の電圧依存性を計算し た。グラフェンと電極の間に電圧を印加することで, グラ フェンと電極が帯電するとともに, グラフェン／窒化ボロ ン界面の電子構造が電極電場によって変化する。グラフェ ンがディラックコーン型の電子構造をもち, 窒化ボロンは バンドギャップを持つ。そのため, 界面での電子移動障壁 は,フェルミレベルと窒化ボロンの伝導帯の間のエネル ギーギャップで決定づけられる。従って, Figure 9 (a) に 示したように，電圧の印加でグラフェンに電子が注入され るにつれて，フェルミレベルとディラック点の間のエネル ギー差が増加する $(\Delta \mathrm{A})$ とともにエネルギーギャップが変 
化する $(\Delta \mathrm{B})$ 。

電圧を $0 \mathrm{~V}$ から $60 \mathrm{~V}$ にした時のバンドエネルギーの変化 を Figure 9 (b) に示す。窒化ボロン膜が十分厚い $900 \mathrm{~nm}$ の時には $\Delta \mathrm{A}$ と $\Delta \mathrm{B}$ のいずれも $0.2 \mathrm{eV}$ 程度の変化量であり, 類似の実験系を再現する結果が得られた 60 。膜厚を $3 \mathrm{~nm} に$ すると変化は小さくなり, 同様の振る舞いが実験からも報 告されている ${ }^{61}$ 。更に, 窒化ボロンの膜厚が $900 \mathrm{~nm}$ の時 には， $\Delta \mathrm{A}$ と $\Delta \mathrm{B}$ は絶対值にしてほぼ同じだが， $3 \mathrm{~nm}$ では 大きさに差がある (青矢印)。これは, 膜厚が $3 \mathrm{~nm}$ だと, 窒化ボロンの伝導体のエネルギーが電極電場によって顕著 に変化するためである。そこで電子構造変化の機構を解析 したところ，電子の流出入で生じる電場と対電極の及ぼす 電場の強さが膜厚に依存して変化するために, 界面領域の 電子移動障壁の電圧依存性が変化するということが明らか になった。

\section{5. 終わりに}

ナノ界面系における光や電圧に対する電子系の応答機構 について, 著者らの理論研究を中心に説明した。超並列第 一原理計算を通じて, ナノ界面系の光励起電子ダイナミク スの機構解明を推し進めてきた。また, 電圧を露わに考慮 して電子状態を計算する手法を開発し, ナノ界面系の電圧 印加による電子物性変化の機構を明らかにした。ナノ界面 系は，境界を持つという有限孤立系と密に詰まった準位間 での電子の柔軟な応答というバルクの系の両者の特徵を有 している。それ故に，いずれとも異なる多彩な応答が発現 することを明らかにしてきた。

ナノ界面系の分子科学がこれから更に発展していく中で, 今回紹介した著者らの研究は基盤になる役割を担うと期待 される。開発してきた方法論は, プログラムが比較的シン プルであるために改良しやすい。従って, 他の様々な理論 計算手法と融合して拡張することが可能である。例えば, 固液界面における物理化学現象を理解するためには, 界面 近傍の溶媒和に対する分子レベルの知見が求められる。本 総説では誘電体理論で溶媒和を取り込んだ研究を紹介した が, 分子動力学法や RISM 法といった分子レベルで溶媒和 を扱う方法論を用いた研究も盛んに行われている ${ }^{62,63}$ 。著 者らは, RISM 法とともに分子性液体に対する拡散方程式 と線形応答理論を組み合わせることで，固体表面近傍の液 体構造の長時間ダイナミクスを取り扱うための手法を開発 している64。そうした手法と本稿の方法論を融合すること で, 例えば, 動作環境下での電極反応の分子論的理解へと 研究を展開することが可能である。また, 外場による幾何 構造変化のダイナミクスを計算するための手法も着実に開 発が進められている ${ }^{65}$ 。原子核の運動を露わに考慮するこ とで, 外場のエネルギーが電子からフォノンへと移る機構 を議論することができる。一方で著者らは, 周波数に依存 性した誘電率を有する誘電体モデルを用いることで, 外界
へのエネルギーの流出を取り扱う方法論を開発している ${ }^{66}$ 。 従って, 熱へのエネルギー変換・散逸を露わに考慮して外 場応答のダイナミクスを原子・電子のレベルで明らかにす るための方法論は確立しつつある。外場を用いた触媒反応 やエネルギー変換について, 応用開発の観点からの研究が 盛んに進められている一方で, 基礎的メカニズムの理解は 深まっていない。実験・理論双方の分子科学的アプローチ による研究が求められる。理論計算手法の更なる開発と適 用を通じて理解に貢献していきたいと考えている。

本研究は多くの皆様に支えられて行うことができました。分子 科学研究所の信定克幸先生には数多くの貴重なご助言を頂きまし た。また, 野田真史博士を始めとする信定グループの方々に多大 なご協力を頂きました。その他にも数々の共同研究者や同僚に支 えて頂いたおかげで，研究を進めることができました。皆様方に 厚く御礼申し上げます。

\section{文献}

(1) Jin, R. Nanoscale 2014, 7, 1549-1565.

(2) Kurashige, W.; Niihori, Y.; Sharma, S.; Negishi, Y. J. Phys. Chem. Lett. 2014, 5, 4134-4142.

(3) Häkkinen, H. Chem. Soc. Rev. 2008, 37, 1847-1859.

(4) Geim, A. K.; Grigorieva, I. V. Nature 2013, 419, 419-425.

(5) Hartland, G. V. Chem. Rev. 2011, 111, 3858-3887.

(6) Maier, S. A. In Plasmonics: fundamentals and applications; Springer, 2007.

(7) Kreibig, U.; Vollmer, M. In Optical properties of metal clusters; Springer Science, 2013.

(8) Liu, M.; Yin, X.; Ulin-Avila, E.; Geng, B.; Zentgraf, T.; Ju, L.; Wang F.; Zhang, X. Nature 2011, 474, 64-67.

(9) Novoselov, K. S.; Geim, A. K.; Morozov, S. V.; Jiang, D.; Katsnelson, M. I.; Grigorieva, I. V.; Dubonos, S. V.; Firsov, A. A. Nature 2005, 438, 197-200.

(10) Sze, S. M.; Ng, K. K. In Physics of Semiconductor Devices; Wiley-Interscience, 2006.

(11) Zhang, Y.; Tang, T.-T.; Girit, C.; Hao, C.; Martin, M. C.; Zettl, A.; Crommie, M. F.; Shen, Y. R.; Wang, F. Nature 2009, 459, $820-823$.

(12) Jackson, J. D. In Classical electromagnetics; Wiley, 1999.

(13) Noda, M.; Sato, S.; Hirokawa, Y.; Uemoto, M.; Takeuchi, T.; Yamada, S.; Yamada, A.; Shinohara, Y.; Yamaguchi, M.; Iida, K.; Floss, I.; et al., Comput. Phys. Commun. 2019, 235, 356-365.

(14) Atwater, H. A. Scientific American 2007, 296, 56-63.

(15) Scholl, J. A. Koh, A. L.; Dionne, J. A. Nature 2012, 483, 421 427.

(16) Savage, K. J.; Hawkeye, M. M.; Esteban, R.; Borisov, A. G.; Aizpurua, J.; Baumberg, J. J. Nature 2012, 491, 574-577.

(17) Iida, K.; Noda, M.; Ishimura, K.; Nobusada, K. J. Phys. Chem. A 2014, 118, 11317-11322.

(18) Alvarez, M. M.; Khoury, J. T.; Schaaff, T. G.; Shafigullin, M. N.; Vezmar, I.; Whetten, R. L. J. Phys. Chem. B 1997, 101, 37063712 .

(19) Zeng, C.; Chen, Y.; Kirschbaum, K.; Appavoo, K.; Sfeir, M. Y.; Jin, R. Sci. Adv. 2015, 1, e1500045. 
(20) Dass, A.; Theivendran, S.; Nimmala, P. R.; Kumara, C.; Jupally, V. R.; Fortunelli, A.; Sementa, L.; Barcaro, G.; Zuo, X.; Noll, B. C. J. Am. Chem. Soc. 2015, 137, 4610-4613.

(21) Iida, K. Noda, M.; Nobusada, K. J. Phys. Chem. C 2016, 120, $2753-2759$.

(22) Hwang, H. Y.; Iwasa, H. Y.; Kawasaki, M.; Keimer, B.; Nagaosa, N.; Tokura, Y. Nat. Mater. 2012, 11, 103-113.

(23) Atwater, H. A.; Polman, A. Nat. Mater. 2010, 9, 205-213.

(24) Li, J.; Cushing, S. K.; Meng, F.; Senty, T. R.; Bristow, A. D.; Wu, N. Nat. Photon. 2015, 9, 601-607.

(25) Clavero, C. Nat. Photon. 2014, 8, 95-103.

(26) Brongersma, M. L.; Halas, N. J. Nordlander, P. Nat. Nanotech. 2015, 10, 25-34.

(27) Kazuma, E.; Sakai, N.; Tatsuma, T. Chem. Comm. 2011, 47, 5777-5779.

(28) Tan, S.; Argondizzo, A.; Ren, J.; Liu, L.; Zhao, J. Petek, H. Nat. Photon. 2017, 11, 806-812.

(29) Iida, K.; Noda, M. npj Comput. Mater. 2020, 6, 5.

(30) Tan, S.; Dai, Y.; Zhang, S.; Liu, L.; Zhao, J.; Petek, H. Phys. Rev. Lett. 2018, 120, 126801.

(31) Roy, K.; Padmanabhan, M.; Goswami, S.; Sai, T. P.; Ramalingam, G.; Raghavan, S.; Ghosh, A. Nat. Nanotech. 2013, 8, 826-830.

(32) Chang, K.; Mei, Z.; Wang, T.; Kang, Q.; Ouyang, S.; Ye, J. ACS Nano 2014, 8, 7078-7087.

(33) Liu, Q.; Cook, B.; Gong, M.; Gong, Y.; Ewing, D.; Casper, M. Stramel, A.; Wu, J. ACS Appl. Mater. Inter. 2017, 9, $12728-$ 12733.

(34) Iida, K.; Noda, M.; Nobusada, K. J. Phys. Chem. C 2018, 122, $21651-21658$.

(35) Bockris, J. O.; Khan, S. U. M. In Surface electrochemistry: a molecular level approach; Springer Science, 2013.

(36) Chen, D.; Tang, L.; Li, J. Chem. Soc. Rev. 2010, 39, 3157-3180.

(37) Lee, H.; Paeng, K.; Kim, I. S. Synth. Metals 2018, 244, 36-47.

(38) Britnell, L.; Gorbachev, R. V.; Jalil, R.; Belle, B. D.; Schedin, F.; Mishchenko, A.; Georgiou, T.; Katsnelson, M. I.; Eaves, L.; Morozov, S. V.; et al., Science 2012, 335, 947-950.

(39) Kneipp, K.; Moskovits, M.; Kneipp, H. Top. Appl. Phys. 2006, 103.

(40) Nakatsuji, H. J. Chem. Phys. 1987, 87, 4995-5001.

(41) Anderson, A. B.; Kang, D. B. J. Phys. Chem. A 1998, 102, 5993-5996.

(42) Tavernelli, I.; Vuilleumier, R.; Sprik, M. Phys. Rev. Lett. 2002, $88,213002$.

(43) Norskov, J. K.; Rossmeisl, J.; Logadottir, A.; Lindqvist, L. R. K.
J.; Kitchin, J. R.; Bligaard, T.; Jonsson, H. J. Phys. Chem. B 2004, 108, 17886-17892.

(44) Taylor, C. D.; Wasileski, S. A.; Filhol, J. S.; Neurock, M. Phys. Rev. B 2006, 73, 1457.

(45) Mermin, N. D. Phys. Rev. 1965, 137, A1441-A1443.

(46) Otani, M.; Sugino, O. Phys. Rev. B 2006, 73, 115407.

(47) Lozovoi, A. Y.; Alavi, A.; Kohanoff, J. Lynden-Bell, R. M. J. Chem. Phys. 2001, 115, 1661-1669.

(48) Bureau, C. Lecayon, G. J. Chem. Phys. 1997, 106, 8821-8829.

(49) Schneider, W. B.; Auer, A. A. Beil. J. Nanotech. 2014, 5, $668-$ 676.

(50) Jacobi, S. Baer, R. J. Chem. Phys. 2005, 123, 044112.

(51) Iida, K.; Yasuike, T.; Nobusada, K. J. Chem. Phys. 2013, 139, 104101.

(52) Hachiyal, T. Itaya, K. Ultramicroscopy 1992, 42-44, 445-452.

(53) Neugebauer, J.; Scheffler, M. Phys. Rev. B 1992, 46, $16067-$ 16080.

(54) Hyman, M. P. Medlin, J. W. J. Phys. Chem. B 2005, 109, 63046310 .

(55) Karlberg, G. S.; Rossmeisl, J. Norskov, J. K. Phys. Chem. Chem. Phys. 2007, 9, 5158-5161.

(56) Deshlahra, P.; Wolf, E. E.; Schneider, W. F. J. Phys. Chem. A 2009, 113, 4125-4133.

(57) Iida, K. Nobusada, K. Phys. Chem. Chem. Phys. 2016, 18 , $15639-15644$.

(58) Tao, L.; Cinquanta, E.; Chiappe, D.; Grazianetti, C.; Fanciulli, M.; Dubey, M.; Molle, A. Akinwande, D. Nat. Nanotech. 2015, $10,227-231$.

(59) Iida, K.; Noda, M.; Nobusada, K. J. Chem. Phys. 2017, 146, 084706.

(60) Parui, S.; Pietrobon, L.; Ciudad, D.; Velez, S.; Sun, X.; Casanova, F.; Stoliar, P.; Hueso, L. E. Adv. Funct. Mater. 2015, 25, $2972-$ 2979.

(61) Sata, Y.; Moriya, R.; Morikawa, S.; Yabuki, N.; Masubuchi, S.; Machida, T. Appl. Phys. Lett. 2015, 107, 023109.

(62) Hirata, F. In Molecular theory of solvation; Springer, 2003; Vol. 24.

(63) Frenkel, D.; Smit, B. In Understanding molecular simulation: from algorithms to applications; Elsevier, 2001.

(64) Iida, K.; Sato, H. J. Chem. Phys. 2012, 136, 244502.

(65) Yamada, A. Yabana, K. Phys. Rev. B 2019, 99, 245103

(66) Iida, K.; Noda, M.; Nobusada, K. J. Chem. Phys. 2015, 142, 214702 .

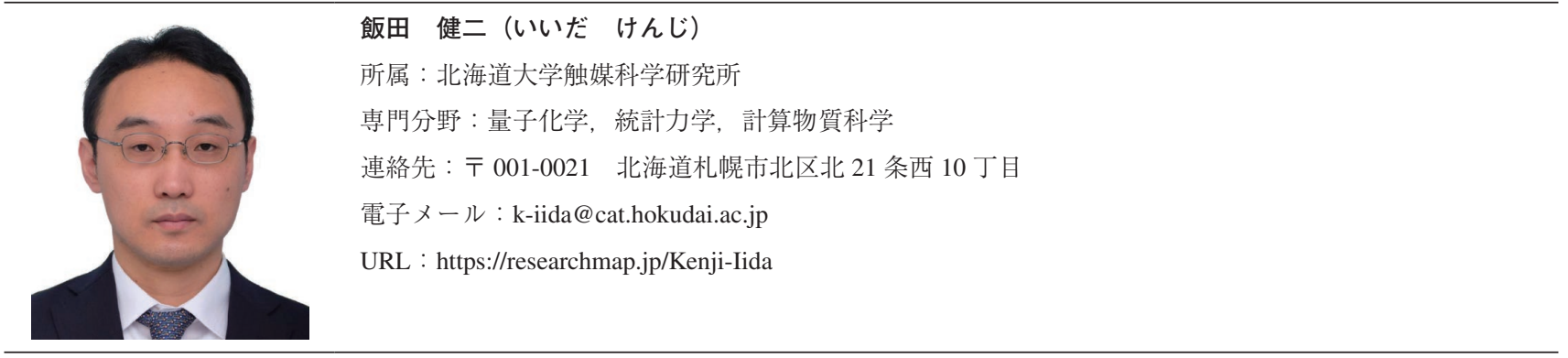

